\title{
Antimycotic efficiency of essential oils and ethanol extracts of some medicinal plants in Egypt
}

\author{
Youssef, M. S. ${ }^{1}$, Saber, S. M. ${ }^{1}$, Arafa, R. F. ${ }^{2}$, Hassane, A. M. A ${ }^{2}$. \\ ${ }^{1}$ Botany Department, Faculty of Science, Sohag University, Egypt. \\ ${ }^{2}$ Botany and Microbiology Department, Faculty of Science, Al-Azhar University, Assiut, Egypt.
}

Rec. 2 Jan, 2013 Accept. 27 Jan, 2013

\begin{abstract}
The antimycotic activity of essential oils and ethanol extracts of seven species of medicinal plants namely; garlic, galangal, cinnamon, eucalyptus, elecampane, basil and clove were assayed against the growth of five pathogenic fungi; Aspergillus flavus, A. niger, A. ostianus, Alternaria alternata and Fusarium solani in addition to Candida albicans (pathogenic yeast) by disc diffusion method. The results revealed that garlic essential oil had broad-spectrum activity against all tested fungi followed by clove, cinnamon, elecampane, basil, galangal and eucalyptus. Clove ethanol extract had broad-spectrum activity against all tested fungi followed by elecampane and cinnamon. Minimum inhibitory concentration (MIC) and qualitative phytochemical screening were carried out for the wide spectrum highly active antimycotic extracts. Garlic, cinnamon, elecampane and clove essential oils and cinnamon, elecampane and clove ethanol extracts were chosen to undergo the minimum inhibitory concentration (MIC) determination and qualitative phytochemical screening. Both clove essential oil and ethanol extract, compared to the other extracts, exhibited the best antimycotic activity and lowest MIC in concentration.
\end{abstract}

Key words: Medicinal plants, antimycotic, essential oils, ethanol extracts, MIC, phytochemical screening.

\section{Introduction}

The World Health Organization defined a medicinal plant as any herbal preparation produced by subjecting plant materials to extraction, fractionation, purification, concentration or other physical or biological process which may be produced for immediate consumption or as a basis for herbal products (WHO, 2001). Phytochemicals often referred to as "secondary metabolities" chemical compounds formed during the plant normal metabolic processes, they were first described at the beginning of the $19^{\text {th }}$ century (Cordell, 1995). The most important of these bioactive compounds of plants are alkaloids, flavanoids, quinones, phenolic compounds, saponins, tannins, coumarins, glycosides, gums, polysaccharides, terpenes and other chemical compounds (Leon et al., 2001; Okwu, 2004; Edeoga et al., 2005; Al-Zubaydi et al., 2009).
In recent years, multiple drug/chemical resistance in both human and plant pathogenic microorganisms have been developed due to indiscriminate use of commercial antimicrobial drugs/chemical commonly used in the treatment of infectious diseases (Anwar et al., 2009). In addition, antibiotics are sometimes associated with adverse effects on the host including hypersensitivity, immunesuppression and allergic reactions (Ahmad et al., 1998; Ababutain, 2011). This situation has forced scientists to search new antimicrobial substances in various sources like medicinal plants (Kumar et al., 2006; Bolivara et al., 2011). Higher plants have been shown to be a potential source for new antimicrobial agents (Kuete et al., 2009; Renisheya et al., 2011).

Medicinal plants have been a source of wide variety of biologically active compounds for many centuries and used extensively as crude

\footnotetext{
* Corresponding author:

Dr. Youssef, M. S

凶youssefm2006@yahoo.com
} 
material or as pure compounds for treating various disease conditions (Borris, 1996). The presence of antifungal compounds in higher plants has long been recognized as an important factor in disease resistance. Such compounds, being biodegradable and selective in their toxicity, are considered valuable for controlling some plant diseases. In addition, plant extracts might have inhibitors to enzymes from the invading pathogens, and the effects of different phenolic compounds on the germination and growth of many fungal pathogens have been reported (Siva et al., 2008).

Mould growth is commonly controlled using synthetic antimicrobials; however, natural antimicrobials had also demonstrated important antifungal properties (Lopez-Malo et al., 2000). Superficial fungal infections, dermatomycoses, are probably the most common communicable fungal disease affecting humans. They have become a serious problem in immunocompromised patients (Pujol et al., 2002). Candida albicans is the most common causative agent of oral candidiasis (Barchiesi et al., 1993). Oral candidiasis is the earliest and most frequent fungal infection in the HIV-infected patients (Reichart, 2003).

Plants that are traditionally used in the treatment of fungal infections or related ailments could be a good source for new, safe, biodegradable and renewable antifungal drugs (Hamza et al., 2006). As aromatic plants, herbs and spices have been used for ages both as flavouring agents and as preservatives of food, they may be effective sources of biodegradable fungitoxicants without harmful side effects (Sokovic et al., 2009). Reports by several authors (Zohri et al., 1995; Youssef, 1995; Youssef and El-Maghraby, 2000; Pradeep et al., 2003; Reddy et al., 2009) support the fact that extracts of certain spices and herbs of medicinal importance exhibit antifungal and antidermatophytic property. These natural antifungal agents can be potentially exploited in controlling the growth of fungi and consequently, inhibiting aflatoxin formation (Yin and Cheng, 1998).

The search for natural sources of antifungal additives that are safe and efficient to be used in food has shown that extracts and essential oils from spices, herbs, and other plants carry antifungal activity (Fan and Chen, 1999; Juglal et al., 2002; Sokovic et al., 2009). Some compounds have been cited as being capable of inhibiting toxigenic species growth, as well as mycotoxin production (Gowda et al., 2004; Marin et al., 2004; Sanchez et al., 2004).

The current study deals with the inhibitory effects of each of essential oils and ethanol extracts of seven different medicinal plant kinds tested on growth of five pathogenic fungi in addition to Candida albicans as pathogenic yeast. Minimum inhibitory concentration (MIC) and qualitative phytochemical screening were carried out for the wide spectrum highly active antimycotic extracts.

\section{Materials and Methods: \\ Collection of Medicinal Plant Samples:}

Seven species of medicinal plants belonging to six taxonomic botanical families were collected from local retail markets of drugs, spices and herbs "Attarin" in Egypt (table, 1).

\begin{tabular}{|c|c|c|c|c|c|}
\hline No. & Arabic name & Latin name & English name & Plant part used & Family name \\
\hline 1 & الثوم & Allium sativum $\mathrm{L}$. & Garlic & Bulblets & Liliaceae \\
\hline 2 & خلنجان & Alpinia galanga Will. & Galangal & Rhizomes & Zingiberaceae \\
\hline 3 & القرفة & Cinnamomum zeylanicum $\mathrm{L}$. & Cinnamon & Bark & Lauraceae \\
\hline 4 & الكافور & Eucalyptus globulus Labill. & Eucalyptus & Leaves & Myrtaceae \\
\hline 5 & عرق جناح & Inula helenium $\mathrm{L}$. & Elecampane & Rhizomes & Asteraceae \\
\hline 6 & 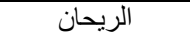 & Ocimum basilicum $\mathrm{L}$. & Basil & Seeds & Lamiaceae \\
\hline 7 & 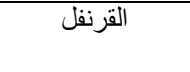 & $\begin{array}{l}\text { Syzygium aromaticum (Linn.) } \\
\text { Merr. \& Perry. }\end{array}$ & Clove & Floral buds & Myrtaceae \\
\hline
\end{tabular}

Table (1): Different investigated species of medicinal plants collected during this study, Arabic name, Latin name, English name, Plant part used and Family name of each kind used. 


\section{Preparation of Plant Extracts:}

Sequential extraction method was employed to extract the plant powders using n-hexane and ethanol 95\% (Pandey, 2007).

Antimycotic Activities of Essential Oils and Ethanol Extracts of Different Kinds of Medicinal Plants:

\section{a) Agar disc diffusion method:}

The antimicrobial activities of different plant extracts were carried out by agar disc diffusion method (NCCLS, 1993). Disc diameter was $5 \mathrm{~mm}$. Nystatine was used as positive control, while n-hexane, Dimethylsulfoxide (DMSO) and ethanol were used as negative control.

Sabouraud's dextrose and $1 \%$ glucoseCzapek's plates previously inoculated with a spore suspension of yeasts and moulds, respectively were used for antimycotic activity.

\section{b) Organisms:}

Five isolates of fungi were used as test organisms. These isolates were Aspergillus flavus Link, A. niger Van Tieghem, A. ostianus Wehmer, Alternaria alternata (Fries) Keissler and Fusarium solani (Mart.) Saccardo. In addition to the previous fungi, one isolate of Candida albicans (Robin) Berkhout was used as the test organism.

\section{Determination of Minimum Inhibitory Concentration (MIC):}

The diameter of the inhibition zone around the disc, measured in millimeter, is used as positive bioactivity. MIC was determined according to (Lamikanra, 1999) and employed by Ayoola et al. (2008a,b).

\section{Qualitative Phytochemical Analysis:}

Phytochemical screening for the presence of glycosides, alkaloids, tannins, flavonoids, saponins, terpenoids and coumarins was undertaken using standard qualitative methods as described by Trease and Evans (1989), Fadeyi et al. (1989), Harbone (1991), Sofowora (1993), Finar (2003) and Parekh et al. (2006).

\section{Results:}

Essential oils and ethanol extracts were tested against the growth of pathogenic fungi
Aspergillus flavus, A. niger, A. ostianus, Alternaria alternata and Fusarium solani in addition to Candida albicans (pathogenic yeast) by disc diffusion method. The data recorded in tables $(2 \& 3)$ revealed that essential oils were more active on the mycotic growth than ethanol extracts.

Garlic essential oil had wide spectrum highly antimycotic activity against all tested fungi followed by clove, cinnamon, elecampane, basil, galangal and eucalyptus. Ethanol extracts occupied the second order in antimycotic activity. Aspergillus flavus was sensitive to cinnamon and clove, with different degrees, while Aspergillus niger and Aspergillus ostianus were sensitive to clove, cinnamon, elecampane, basil and galangal ethanol extracts (table, 2).

Alternaria alternata was the most sensitive fungus to the ethanol extracts. Its growth was affected by clove, elecampane, basil, galangal, cinnamon and eucalyptus. Clove, basil, elecampane and cinnamon had antimycotic activity with different degrees upon the growth of Fusarium solani.

Garlic ethanol extract was not effective against the growth of all tested fungal species. Clove essential oil was the highly active against Candida albicans, followed by cinnamon, garlic, basil essential oils. Elecampane, eucalyptus and galangal essential oils had weak activity on Candida albicans. The ethanol extract of clove was the highly active against the growth of Candida albicans, while cinnamon came second. Elecampane, basil and eucalyptus were also effective against Candida albicans (table, 3 ).

Based on the results in table (4), the MICs of garlic essential oil on the growth of Aspergillus flavus, A. niger, A. ostianus, Alternaria alternata, Fusarium solani and Candida albicans were 94.19, 109.64, >500, 58.1, 66.7 and $500 \mathrm{mg} / \mathrm{ml}$. For cinnamon essential oil, the MICs were $>500,500,82.22$, $81.28,208.93$ and $148.93 \mathrm{mg} / \mathrm{ml}$. Moreover, the data showed that the MICs of elecampane essential oil were $>500,500,>500,94.18$, 75.85 and $62.51 \mathrm{mg} / \mathrm{ml}$, and for clove were 
$85.86,37.41,46.77,111.43,33.88$ and 31.11 $\mathrm{mg} / \mathrm{ml}$.

On the other hand, the results in table (4) presented the MICs of the ethanol extracts of cinnamon, clove and elecampane against the preceding tested fungi and showed that the MICs of cinnamon were 500, 500, 112.2, 100, 151.35 and $63.1 \mathrm{mg} / \mathrm{ml}$, elecampane 250,500 , $500,63.1,23.44$ and $123.02 \mathrm{mg} / \mathrm{ml}$ and clove $6.22,158.49,500,11.48,114.81$ and 98.62 $\mathrm{mg} / \mathrm{ml}$.

From the results outlined in table (5), we can conclude that the phytochemical analysis of garlic essential oil showed the presence of flavonoids, terpenoids and glycosides. As well as, clove essential oil contained the same constituents in addition to coumarins. All tested phytochemicals were found in the essential oil of cinnamon except tannins and saponins, while elecampane essential oil contained flavonoids and alkaloids in addition to terpenoids.

On the other hand, terpenoids were detected in all tested ethanol extracts, while flavonoids and coumarins were absent in cinnamon and clove, respectively. Both glycosides and coumarins were present in cinnamon, while flavonoids, alkaloids, coumarins and terpenoids were present in elecampane ethanol extract. Clove ethanol extract also had flavonoids, glycosides and tannins.

\begin{tabular}{|c|c|c|c|c|c|c|}
\hline $\begin{array}{c}\text { Medicinal } \\
\text { plant }\end{array}$ & $\begin{array}{c}\text { Aspergillus } \\
\text { flavus }\end{array}$ & $\begin{array}{c}\text { Aspergillus } \\
\text { niger }\end{array}$ & $\begin{array}{c}\text { Aspergillus } \\
\text { ostianus }\end{array}$ & $\begin{array}{c}\text { Alternaria } \\
\text { alternata }\end{array}$ & $\begin{array}{c}\text { Fusarium } \\
\text { solani }\end{array}$ & $\begin{array}{c}\text { Candida } \\
\text { albicans 48 h }\end{array}$ \\
\hline Garlic & 40 & 27 & 30 & 44 & 42 & 20 \\
\hline Galangal & 8 & 8 & 8 & 17 & 15 & 9 \\
\hline Cinnamon & 25 & 16 & 20 & 17 & 30 & 21 \\
\hline Eucalyptus & 8 & 9 & 9 & 12 & 15 & 11 \\
\hline Elecampane & 14 & 16 & 13 & 15 & 20 & 11 \\
\hline Basil & 14 & 10 & 11 & 14 & 12 & 14 \\
\hline Clove & 28 & 35 & 40 & 40 & 28 & 26 \\
\hline Nystatine & 10 & 7 & NI & 12 & 10 & 8 \\
\hline $\begin{array}{c}\text { n-hexane or } \\
\text { DMSO }\end{array}$ & NI & NI & NI & NI & NI & NI \\
\hline
\end{tabular}

Table (2): Antimycotic activities of the essential oils of the investigated plants against fungal strains [After $72 \mathrm{~h}$ ]. Inhibition zone diameter in millimeter ( $\mathrm{mm})$.

$\mathrm{NI}=$ No Inhibition

\begin{tabular}{|c|c|c|c|c|c|c|}
\hline $\begin{array}{c}\text { Medicinal } \\
\text { plant }\end{array}$ & $\begin{array}{c}\text { Aspergillus } \\
\text { flavus }\end{array}$ & $\begin{array}{c}\text { Aspergillus } \\
\text { niger }\end{array}$ & $\begin{array}{c}\text { Aspergillus } \\
\text { ostianus }\end{array}$ & $\begin{array}{c}\text { Alternaria } \\
\text { alternata }\end{array}$ & $\begin{array}{c}\text { Fusarium } \\
\text { solani }\end{array}$ & $\begin{array}{c}\text { Candida } \\
\text { albicans 48 h }\end{array}$ \\
\hline Garlic & NI & NI & NI & NI & NI & NI \\
\hline Galangal & NI & 8 & 7 & 12 & NI & NI \\
\hline Cinnamon & 7 & 9 & 20 & 11 & 10 & 24 \\
\hline Eucalyptus & NI & NI & NI & 10 & NI & 7 \\
\hline Elecampane & 8 & 9 & 8 & 40 & 12 & 9 \\
\hline Basil & NI & 7 & 7 & 13 & 14 & 8 \\
\hline Clove & 20 & 25 & 25 & 40 & 28 & 25 \\
\hline Nystatine & 10 & 7 & NI & 12 & 10 & 8 \\
\hline $\begin{array}{c}\text { Ethanol or } \\
\text { DMSO }\end{array}$ & NI & NI & NI & NI & NI & NI \\
\hline
\end{tabular}

Table (3): Antimycotic activities of the ethanol crude extracts of the investigated plants against fungal $\mathrm{NI}=$ No Inhibition strains [After $72 \mathrm{~h}$ ]. Inhibition zone diameter in millimeter ( $\mathrm{mm})$. 


\begin{tabular}{|c|c|c|c|c|c|c|c|}
\hline $\begin{array}{l}\text { Type of } \\
\text { extract }\end{array}$ & $\begin{array}{c}\text { Medicinal } \\
\text { plant }\end{array}$ & $\begin{array}{c}\text { Aspergillu } \\
\text { s flavus }\end{array}$ & $\begin{array}{l}\text { Aspergillu } \\
\text { s niger }\end{array}$ & $\begin{array}{l}\text { Aspergillu } \\
\text { s ostianus }\end{array}$ & $\begin{array}{c}\text { Alternari } \\
\text { a } \\
\text { alternata }\end{array}$ & $\begin{array}{l}\text { Fusariu } \\
\text { m solani }\end{array}$ & $\begin{array}{c}\text { Candid } \\
\text { a } \\
\text { albicans }\end{array}$ \\
\hline \multirow{4}{*}{$\begin{array}{c}\text { n-hexane } \\
\text { (essentia } \\
\text { l oils) }\end{array}$} & Garlic & 94.19 & 109.64 & $>500$ & 58.1 & 66.7 & 500 \\
\hline & Cinnamon & $>500$ & 500 & 82.22 & 81.28 & 208.93 & 148.93 \\
\hline & $\begin{array}{c}\text { Elecampan } \\
\text { e }\end{array}$ & $>500$ & 500 & 500 & 94.18 & 75.85 & 62.51 \\
\hline & Clove & 85.86 & 37.41 & 46.77 & 111.43 & 33.88 & 31.11 \\
\hline \multirow{3}{*}{$\begin{array}{c}\text { Ethanol } \\
\mathbf{9 5 \%}\end{array}$} & Cinnamon & 500 & 500 & 112.2 & 100 & 151.35 & 63.1 \\
\hline & $\begin{array}{c}\text { Elecampan } \\
\mathrm{e}\end{array}$ & 250 & 500 & 500 & 63.1 & 23.44 & 123.02 \\
\hline & Clove & 6.22 & 158.49 & 500 & 11.48 & 114.81 & 98.62 \\
\hline
\end{tabular}

Table (4): MICs (mg/ml) of essential oils and ethanol extracts of investigated medicinal plant species with wide spectrum highly antimycotic activities against tested fungi.

\begin{tabular}{|c|c|c|c|c|c|c|c|c|}
\hline $\begin{array}{l}\text { Type of } \\
\text { extract }\end{array}$ & $\begin{array}{l}\text { Medicinal } \\
\text { plant }\end{array}$ & $\begin{array}{c}\text { Flavonoi } \\
\text { ds }\end{array}$ & $\begin{array}{c}\text { Alkaloi } \\
\text { ds }\end{array}$ & $\begin{array}{l}\text { Terpenoi } \\
\text { ds }\end{array}$ & $\begin{array}{l}\text { Glycosid } \\
\text { es }\end{array}$ & $\begin{array}{c}\text { Coumari } \\
\text { ns }\end{array}$ & $\begin{array}{c}\text { Tanni } \\
\text { ns }\end{array}$ & $\begin{array}{c}\text { Saponi } \\
\text { ns }\end{array}$ \\
\hline \multirow{4}{*}{$\begin{array}{c}\text { n- } \\
\text { hexane } \\
\text { (essenti } \\
\text { al oils) }\end{array}$} & Garlic & + & - & + & + & - & - & - \\
\hline & Cinnamon & + & + & + & + & + & - & - \\
\hline & $\begin{array}{c}\text { Elecampa } \\
\text { ne }\end{array}$ & + & + & + & - & + & - & - \\
\hline & Clove & + & - & + & + & + & - & - \\
\hline \multirow{3}{*}{$\begin{array}{c}\text { Ethanol } \\
95 \%\end{array}$} & Cinnamon & - & - & + & + & + & - & - \\
\hline & $\begin{array}{c}\text { Elecampa } \\
\text { ne }\end{array}$ & + & + & + & - & + & - & - \\
\hline & Clove & + & - & + & + & - & + & - \\
\hline
\end{tabular}

Table (5): Phytochemical screening of the bioactive compounds in wide spectrum highly active

$+=$ Present $\quad-=$ Absent

\section{Discussion:}

The object of the present experiment was to examine the antimycotic activity of each of essential oils and ethanol extracts of seven different medicinal plant species assayed on the growth of six pathogenic moulds representing fungi (five isolates; Aspergillus flavus, A. niger, A. ostianus, Alternaria alternata and Fusarium solani) in addition to pathogenic yeast species (Candida albicans). Minimum inhibitory concentration (MIC) and qualitative phytochemical screening were carried out for the wide spectrum highly active antimycotic extracts. In the testing procedures used in this investigation, the moulds were grown under near optimum conditions with controlled temperature and adequate nutrients.
The results obtained during this investigation elucidated clearly that generally, pathogenic fungi were more resistant to treatment with different extracts tested. Essential oils were more effective antimycotic agents than ethanol extracts. This conclusion is in full agreement to that previously recorded by several researchers (Youssef, 1995; Thanaboripat et al., 2004, 2005).

The data recorded in current investigation revealed that all essential oils had highly broader antimycotic activity against all tested fungi and these were; basil, cinnamon, clove, elecampane, eucalyptus, galangal and garlic. On the other hand, three ethanol extracts showed highly broader antimycotic activity against all tested fungi (cinnamon, clove and elecampane), whereas ethanol extract of basil 
had moderate antimycotic activity against five fungal species out of six tested. Basil essential oil (Ocimum basilicum) exhibited inhibition activity against Fusarium graminearum, $F$. culmorum, Aspergillus flavus, A. oryzae, A. brasiliensis (Dobre et al., 2011) and A. niger (Hussain et al., 2008).

Data in current study showed that cinnamon essential oil and ethanol extract had highly antifungal activity against all tested fungi. Cinnamon is rich in essential oils and tannins, which inhibit microbial growth (Chang 1995). The major constituent possessing antifungal activity in C. zeylanicum bark and leaf oils were found to be cinnamaldehyde and eugenol, respectively (Mishra et al., 2009). In addition other compounds having fungicidal property have also been reported to be present in bark and leaves (Ranasinghe et al., 2002).

Clove buds oil proved to develop the best antifungal activity against Fusarium graminearum, F. culmorum, Aspergillus flavus, A. oryzae and A. brasiliensis (Dobre et al., 2011). The effects of clove essential oil and its principal component, eugenol, on growth and mycotoxin production by some toxigenic fungal genera such as Aspergillus spp., Penicillium spp., and Fusarium spp. had been reported by Velluti et al. (2003, 2004), Lopez-Malo et al. (2005a,b) and Nesci et al. (2011). This component was able to inhibit both growth and/or mycotoxin production (Passone et al., 2012).

Ayoola et al. (2008b) and Ali et al. (2009) reported that clove essential oil possessed antifungal properties against Candida albicans and showed a broad spectrum of activity. Phenols are known to have antiseptic properties (Pelczar et al., 1998), which is consistent with the antimicrobial data obtained for these compounds. Caryophyllene had also been shown to possess antimicrobial properties, though not as potent as eugenol (Dorman et al., 2000).

Chloroform and essential oil of elecampane exhibited good antidermatophyte activity while aqueous extract had no effect on tested dermatophytes (Youssef, 1995). The essential oil of eucalyptus leaves has been the object of several studies about antibacterial, antioxidant, antihyperglycemic and antifungal activity (Derwich et al., 2009).

Janssen and Scheffer (1985) reported that fresh and dried rhizomes of galangal (Alpinia galanga Will.) showed antimycotic activity against yeast, fungi and some dermatophytes. Fusarium graminearum, $F$. culmorum, Aspergillus flavus, A. oryzae and A. brasiliensis were tested for the antifungal activity of garlic oil. Only $F$. culmorum was inhibited by garlic oil (Dobre et al., 2011). Allium sativum and its components (allicin and its derivatives) were well known to possess antimicrobial activity (Harris et al., 2001).

Antifungal activity of clove and cinnamon oils against A. niger, Alternaria alternata, Colletotrichum gloeosporioides, Lasiodiplodia theobromae, Phomopsis viticola and Rhizopus stolonifer showed minimal inhibitory concentration (MIC) for clove: 200, 200, 400, 800,200 and $200 \mathrm{mg} / \mathrm{ml}$, respectively, whereas the MIC obtained from cinnamon oil were $50,100,200,200,100$ and $800 \mathrm{mg} / \mathrm{ml}$, respectively (Sukatta et al., 2008). Ayoola et al. (2008b) and Ali et al. (2009) reported that clove essential oil possessed anticandidal property against Candida albicans and showed a broad spectrum of activity with minimum inhibitory concentrations (MICs) $0.067 \mathrm{mg} / \mathrm{ml}$ and $(24 \mu \mathrm{g} / \mathrm{ml})$, respectively. The efficacy of cinnamon and clove oils as antifungal agents, were reported by many researchers (Soliman and Badeaa, 2002; Velluti et al., 2003; LopezMalo et al., 2007). Anticandidal activity of crude ethanol extract from clove was evaluated against Candida albicans over a wide range of concentrations (50-5000 ppm), and it was proved most active at MIC $800 \mathrm{ppm}$ $(\mathrm{DIZ}=25 \mathrm{~mm})$ (Dababneh, 2008).

Qualitative analysis was carried out for screening the presence of major pytochemical constituents such as glycosides, alkaloids, tannins, flavonoids, saponins, terpenoids and coumarins in the highly active antimycotic extracts.

Our results are in full agreement with the previous data of several researchers (Mishra $e t$ al., 2009; Pathmanathan et al., 2010; Nan et 
al., 2012). Phytochemical constituents like alkaloids, phenolics, flavonoids, tannins and saponins are usually responsible for medicinal and antimicrobial importance of herbal plants (Krishnaiah et al., 2009). Plants are rich in a wide variety of secondary metabolites such as tannins, alkaloids and flavonoids, which have been found in vitro to have antimicrobial properties (Cowan, 1999). The antimicrobial potency of plants is believed to be due to tannins, saponins, phenolic compounds and flavonoids (Aboaba and Efuwape, 2001).

\section{References:}

Ababutain, I.M. (2011). Antimicrobial activity of ethanolic extracts from some medicinal plants. Australian Journal of Basic and Applied Sciences, 5(11): 678-683.

Aboaba, O. and Efuwape, B.M. (2001). Antibacterial properties of some Nigerian species. Biological Research Communications, 13: 183-188.

Ahmad, I., Mehmood, Z. and Mehmood, I. (1998). Screening of some Indian medicinal plants for their antimicrobial properties. Journal of Ethnopharmacology, 62: 183-193.

Ali, H.S., Kamal, M. and Mohamed, S.B. (2009). In vitro clove oil activity against periodontopathic bacteria. Journal of Science and Technology, 10(1): 1-7.

Al-Zubaydi, S.R., Al-Hmdany, M.A. and Raesan, S.J. (2009). Antibacterial effect of some medicinal plant extracts against some pathogenic bacteria strains. Journal of Duhok University, 12(1): 244-249.

Anwar, F., Ali, M., Hussain, A.I. and Shahid, M. (2009). Antioxidant and antimicrobial activities of essential oil and extracts of fennel (Foeniculum vulgare Mill.) seeds from Pakistan. Flavour and Fragrance Journal, 24: 170-176.

Ayoola, A.G., Johnson, O.O., Adelowotan, T., Aibinu, E. I.; Adenipekun, E.; Adepoju-Bello, A.A., Coker, B.A.H. and Odugbemi, O.T. (2008a).

Evaluation of the chemical constituents and the antimicrobial activity of the volatile oil of Citrus reticulata fruit (Tangerine fruit peel) from South West Nigeria. African Journal of Biotechnology, 7(13): 2227-2231.

Ayoola, G.A., Lawore, F.M., Adelowotan, T., Aibinu, I.E., Adenipekun, E., Coker, H.A.B. and Odugbemi, T.O. (2008b). Chemical analysis and antimicrobial activity of the essential oil of Syzigium aromaticum (clove). African Journal of Microbiology Research, 2: 162166.

Barchiesi, F., Morbiducci, V., Ancarani, F. and Scalise, G. (1993). Emergence of oropharyngeal candidiasis caused by non-albicans species of Candida in HIV-infected patients. European Journal Epidemiology, 9: 455-456.

Bolivara, P., Paredesa, C.C., Hernndezb, L.R., Jurezc, Z.N., Snchez-Arreolab, E., Av-Gaya, Y. and Bacha, H. (2011). Antimicrobial, anti-inflammatory, antiparasitic and cytotoxic activities of Galium mexicanum. Journal of Ethnopharmacology, 137: 141-147.

Borris, R.P. (1996). Natural product research: perspectives from major pharmaceutical companies. Journal of Ethnopharmacology, 51(1-3): 29-38.

Chang, H.W. (1995). Antibacterial effect of spices and vegetables. Food Industries (ROC), 27: 53-61.

Cordell, G.A. (1995). Changing strategies in natural products chemistry: A review. Phytotherapy Research, 4: 198-200.

Cowan, M.M. (1999). Plant products as antimicrobial agents. Clinical Microbiology Reviews, 12: 564-582.

Dababneh, F.B. (2008). Antimicrobial activity of selected Jordanian medicinal plant extracts against pathogenic microorganisms. Journal of Food, Agriculture and Environment, 6(2): 134-139. 
Derwich, E., Benziane, Z. and Boukir, A. (2009). GC/MS analysis of volatile constituents and antibacterial activity of the essential oil of the leaves of Eucalyptus globulus in Atlas Median from Morocco. Advances in Natural and Applied Sciences, 3(3): 305-313.

Dobre, A.A. Gagiu, V. and Niculita, P. (2011). Preliminary studies on the antimicrobial activity of essential oils against food borne bacteria and toxigenic fungi. AUDJG- Food Technology, 35(2): 16-26.

Dorman, H.J.D. and Deans, S.G. (2000). Antimicrobial agents from plants: antibacterial activity of plant volatile oils. Journal of Applied Microbiology, 88: 308-316.

Fadeyi, M.G., Adeoye, A.E. and Olowokodejo, J.D. (1989). Epidermal and phytochemical studies with genus of Boerhavia (Nyetanginaceae). Crude Drug Research, 29: 178-184.

Fan, J.J. and Chen, J.H. (1999). Inhibition of aflatoxin-producing fungi by Welsh onion extracts. Journal of Food Protection, 62: 414-417.

Finar, I.L. (2003). Organic chemistry. Vol. 2: Stereochemistry and the chemistry of natural products. $5^{\text {th }}$ edition. Delhi: Pearson Education (Singapore) India branch, pp. 769-771.

Gowda, N.K.S., Malathi, V. and Suganthi, R.U. (2004). Effect of some chemical and herbal compounds on growth of Aspergillus parasiticus and aflatoxin production. Animal Feed Science and Technology, 116: 281-291.

Hamza, O.J.M., van den Bout-van den Beukel, C.J.P., Matee, M.I.N., Moshi, J.M., Mikx, F.H.M., Selemani, H.O., Mbwambo, Z.H., Van der Ven, A.J.A.M. and Verweij, P.E. (2006), Antifungal activity of some Tanzanian plants used traditionally for the treatment of fungal infections. Journal of Ethnopharmacology, 108: 124-132.

Harborne, J.B. (1991). Phytochemical Methods, A guide to modern techniques of plant analysis, Chapman and Hall, London, pp. 58, 74, 84, 88, 120, 126, 176-201.

Harris, J.C., Cottrell, S.L., Plummer, S. and Lloyd, D. (2001). Antimicrobial properties of Allium sativum. Journal of Applied Microbiology and Biotechnology, 57: 282-286.

Hussain, A.I., Anwar, F., Sherazi, S.T.H. and Przybylski, R. (2008). Chemical composition. Antioxidant and antimicrobial activities of basil (Ocimum basilicum) essential oils depends on seasonal variations. Food Chemistry, 108(3): 986-995.

Janssen, A.M. and Scheffer, J.J.C. (1985). Acetoxychavicol acetate, an antifungal component of Alpinia galanga. Planta Medica, 6: 507-511.

Juglal, S., Govinden, R. and Odhav, B. (2002). Spice oils for the control of cooccurring mycotoxin-producing fungi. Journal of Food Protection, 65: 683687.

Krishnaiah, D., Devi, T., Bono, A. and Sarbatly, A. (2009). Studies on phytochemical constituents of six Malaysian medicinal plants. Journal of Medicinal Plants Research, 3(2): 6772.

Kuete, V., Fozing, D.C., Kapche, W.F.G.D., Mbaveng, A.T., Kuiate, J.R., Ngadjui, B.T. and Abegaz, B.M. (2009). Antimicrobial activity of the methanolic extract and compounds from Morus mesozygia stem bark. Journal of Ethnopharmacology, 124: 551-555.

Kumar, V.P., Chauhan, N.S., Rajani, H.P.M. (2006). Search for antibacterial and antifungal agents from selected Indian medicinal plants. Journal of Ethnopharmacology, 107: 182-188.

Lamikanra, A. (1999). Essential microbiology. 2nd edn. AMKRA, Lagos, Nigeria, pp. 128-129.

Leon, J., Rojo, E. and Sanchezerrano, J. (2001). Wound signaling in plants. 
Journal of Experimental Botany, 52: 1-9.

Lopez-Malo, A., Alzamora, S.M. and Guerrero, S. (2000). Natural antimicrobials from plants. In: Alzamora, S. M.; Tapia, M.S. and Lopez-Malo, A. (Eds.), Minimally Processed Fruits and Vegetables. Fundamentals Aspects and Applications. Aspen Publishers, Gaithersburg, PA, pp. 237-264.

Lopez-Malo, A., Alzamora, S.M. and Palou, E. (2005a). Aspergillus flavus growth in the presence of chemical preservatives and naturally occurring antimicrobial compounds. International Journal of Food Microbiology, 99: 119-128.

Lopez-Malo, A., Alzamora, S.M. and Palou, E. (2005b). Naturally occurring compounds-Plant sources. In Davidson, P. M.; Sofos, J. N. and Branen, A. L. (eds.), Antimicrobials in Foods 3rd ed., New York: Marcel Dekker, pp. 429-451.

Lopez-Malo, A., Barreto-Valdivieso, J., Palou, E. and Martin. S.F. (2007). Aspergillus flavus growth response to cinnamon extract and sodium benzoate mixtures. Food Control, 18: 1358-1362.

Marin, S., Velluti, A., Ramos, A.J. and Sanchis, V. (2004). Effect of essential oils on zearalenone and deoxynivalenol production by Fusarium graminearum in nonsterilized maize grain. Food Microbiology, 21: 313-318.

Mishra, A.K., Mishra, A., Kehri, H.K. Sharma, B. and Pandey, A.K. (2009). Inhibitory activity of Indian spice plant Cinnamomum zeylanicum extracts against Alternaria solani and Curvularia lunata, the pathogenic dematiaceous moulds. Annals of Clinical Microbiology and Antimicrobials, 8: 9.

Nan, M., Pintea, A., Bunea, A., Esianu, S. and Tamas, M. (2012). HPLC analysis of carotenoids from Inula helenium L. flowers and leaves. Farmacia, 60(4): 501-509.

NCCLS (National Committee for Clinical Laboratory Standards), (1993). 3rd Ed. approved standard M7-A3, NCCLS, Villanova, PA.

Nesci, A., Montemarani, A., Passone, M.A. and Etcheverry, M. (2011). Insecticidal activity of synthetic antioxidants, natural phytochemicals, and essential oils against an Aspergillus section Flavi vector (Oryzaephilus surinamensis L.) in microcosm. Journal of Pest Science, 84: 107-115.

Okwu, D.E. (2004). Phytochemicals and vitamin content of indigenous spices of South Eastern Nigeria. Journal of Sustainable Agriculture Environment, 6: 30-34.

Pandey, A.K. (2007). Anti-staphylococcal activity of a pan-tropical aggressive and obnoxious weed Parthenium histerophorus: An in vitro study. National Academy Science Letters, 30: 383-386.

Parekh, J., Karathia, N. and Chanda, S. (2006). Antibacterial activity of Bauhinia variegata. Journal of Biomedical Research, 9: 53-56.

Passone, A.M., Girardi, S.N., Ferrand, A.C. and Etcheverry, M. (2012). In vitro evaluation of five essential oils as botanical fungitoxicants for the protection of stored peanuts from Aspergillus flavus and A. parasiticus contamination. International Biodeterioration \& Biodegradation, 70: 82-88.

Pathmanathan, M.K., Uthayarasa, K., Jeyadevan, J.P. and Jeyaseelan, E.C. (2010). In vitro antibacterial activity and phytochemical analysis of some selected medicinal plants. International Journal of Pharmaceutical \& Biological Archives, 1(3): 291-299. 
Pelczar, M.J., Chan, E.C.S. and Krieg, N.R. (1998). Control of microorganisms, the control of microorganisms by physical agents. In: Microbiology. McGraw-Hill International, New York, pp. 469-509.

Pradeep, A.G., Lokesh, S. and Ravi, V.R. (2003). Efficacy of some essential oils on seed mycoflora and seedling quality of some crop species saved by farmers. Advanced Plant Science, 16: 53-58.

Pujol, I., Capilla, J., Fernandez-Torres, B., Ortoneda, M. and Guarro, J. (2002). Use of the sensititre colorimetric microdilution panel for antifungal susceptibility testing of dermatophytes. Journal of Clinical Microbiology, 40: 2618-2621.

Ranasinghe, L., Jayawardena, B. and Abeywickrama, K. (2002). Fungicidal activity of essential oils of Cinnamomum zeylanicum (L.) and Syzygium aromaticum (L.) Merr. \& Perry against crown rot and anthracnose pathogens isolated from banana. Letters in Applied Microbiology, 35: 208-11.

Reddy, K.R.N., Abbas, H.K., Abel, C.A., Shier, W.T., Oliveira, C.A.F. and Raghavender, C.R. (2009). Mycotoxin contamination of commercially important agricultural commodities. Toxin Reviews, 28: 154-168.

Reichart, P.A. (2003). Oral manifestations in HIV infection: fungal and bacterial infections Kaposi's sarcoma. Medical Microbiology and Immunology, 192: 165-169.

Renisheya, J.J.M.T., Johnson, M., Mary, U.M. and Arthy, A. (2011). Antibacterial activity of ethanolic extracts of selected medicinal plants against human pathogens. Asian Pacific Journal of Tropical Biomedicine, 4(5): 76-78.

Sanchez, E., Heredia, N. and García, S. (2004). Inhibition of growth and mycotoxin production of Aspergillus flavus and Aspergillus parasiticus by extracts of Agave species. International Journal of Food Microbiology, 161: 245-249.

Siva, N., Ganesan, S., Banumathy, N. and Muthuchelian (2008). Antifungal effect of leaf extract of some medicinal plants against Fusarium oxysporum causing wilt disease of Solanum melogena L. Ethnobotanical Leaflets, 12: 156-163.

Sofowora, A. (1993). Medicinal plants and Traditional Medicine in Africa. Spectrum Books, Ibadan, p. 150.

Sokovic, M.D., Vukojevic, J., Marin, P.D., Brkic, D.D., Vajs, V. and Van Griensven, L.J.L.D. (2009). Chemical composition of essential oils of Thymus and Mentha species and their antifungal activities. Molecules, 14: 238-249.

Soliman, K.M. and Badeaa, R.I. (2002). Effect of oil extracted from some medicinal plants on different mycotoxigenic fungi. Food and Chemical Toxicology, 40: 1669-1675.

Sukatta, U., Haruthaithanasan, V., Chantarapanont, W., Dilokkunanant, U. and Suppakul, P. (2008). Antifungal activity of clove and cinnamon oil and their synergistic effect against postharvest decay fungi of grape in vitro. Kasetsart Journal of Natural Science, 42:169-174.

Thanaboripat, D., Suvathi, Y. and Chantarateptawan, V. (2005). Control of growth and aflatoxin production of Aspergillus flavus by medicinal and aromatic plants. In: Study on Plant Pest and Disease Biological Control and Biotechnology, Edited by Yang Qian and $\mathrm{Yu}$ Ziniu, Heilongjiang Science and Technology Press, Harbin, pp. 52-62.

Thanaboripat, D., Monkontanawut, N., Suvathi, Y. and Ruangrattanametee, V. (2004). Inhibition of aflatoxin production and growth of Aspergillus 
flavus by citronella oil. KMITL Science Journal, 49(1): 1-8.

Trease, G.E. and Evans, W.C. (1989). Pharmacognosy. $13^{\text {th }}$ edn. Bailliere Tindall, London, pp. 176-180.

Velluti, A., Sanchis, V., Ramos, A.J. and Marín, S. (2004). Effect of essential oil of cinnamon, clove, lemongrass, oregano and palmarosa on growth and fumonisin $\mathrm{B}_{1}$ production by Fusarium verticillioides in maize grain. Journal of the Science of Food Agriculture, 84: 1141-1146.

Velluti, A., Sanchis, V., Ramos, A. J., Ergido, J. and Marín, S. (2003). Inhibitory effect of cinnamon, clove, lemongrass, oregano and palmarosa essential oils on growth and fumonisin $\mathrm{B}_{1}$ production by Fusarium proliferatum in maize grain. International Journal of Food Microbiology, 89: 145-154.

WHO (World Health Organization), (2001). Legal Status of Traditional Medicine and Complementary /Alternative Medicine: A world wide review. WHO Publishing I. ISBN, 9241545488 .
Yin, M.C. and Cheng, W.S. (1998). Inhibition of Aspergillus niger and Aspergillus flavus by some herbs and spices. Journal of Food Protection, 61(1): 123-125.

Youssef, M.S. (1995). Mycoflora and mycotoxins of some medicinal plants and their antimicrobial activities in Egypt. Ph.D Thesis, Sohag, South Valley University, Egypt.

Youssef, M.S. and El-Maghraby, O.M.O. (2000). Mycotoxicity of some Hair oils against pathogenic dermatophytes and keratinase activity. Bulletin of Faculty of Science, Assiut University, 29 (2-D): 73-82.

Zohri, A.A., Abdel-Gawad, K.M., and Saber, S.M. (1995). Antibacterial, Antidermatophytic and antitoxigenic activities of onion [Allium cepa Z.] oil. The second Regional Mycological Confer. Al-Azhar Univ., Egypt, 1992. Published in Microbial Research, 150: 167-172.

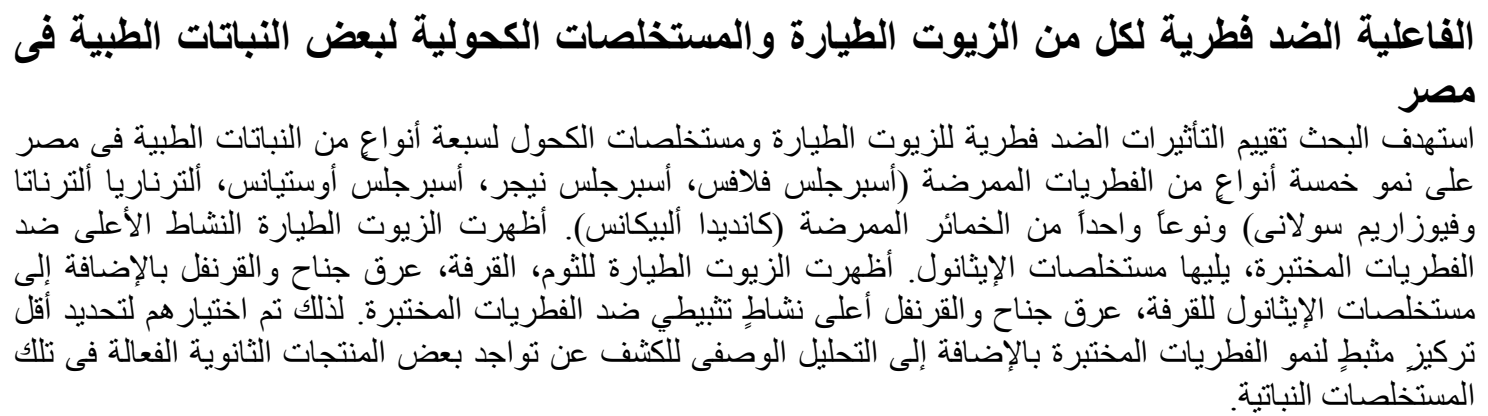

